\title{
PENERAPAN MIND MAPPING DALAM PENDEKATAN SAINTIFIK UNTUK MENINGKATKAN KEMAMPUAN KOMUNIKASI MATEMATIS SISWA DI SMPN 9 KOTA JAMBI
}

\author{
Sri Dewi ${ }^{1}$, Akhmad Faisal Hidayat ${ }^{2}$ \\ Pendidikan Matematika FKIP Universitas Batanghari Jambi ${ }^{1,2}$ \\ Email : dedewsri1982@gmail.com
}

\begin{abstract}
ABSTRAK
Keterampilan komunikasi matematika siswa masih kurang memuaskan, rata-rata kesalahan siswa menunjukkan kesalahan dalam mengekspresikan peristiwa sehari-hari dalam bahasa matematika. Hal ini disebabkan oleh kurangnya pemahaman siswa tentang materi yang telah diajarkan, dan tingkat kreativitas siswa dalam mencatat konsep-konsep penting yang terkandung dalam materi pelajaran masih kurang memuaskan, catatan siswa cenderung masih membosankan. Tujuan dari penelitian ini adalah mendeskripsikan implementasi dan hasil pemetaan pikiran dalam pendekatan ilmiah untuk meningkatkan keterampilan komunikasi matematis siswa. Jenis penelitian yang penulis lakukan termasuk dalam penelitian tindakan kelas (PTK). Penulis menggunakan metode wawancara, observasi, tes dan dokumentasi. Sedangkan untuk analisisnya, penulis menggunakan teknik analisis deskriptif kualitatif, yaitu berupa data kualitatif dan data kuantitatif yang penulis peroleh selama pengamatan langsung di lapangan. Temuan penelitian menunjukkan bahwa penerapan mind mapping dalam pendekatan saintifik dapat meningkatkan keterampilan komunikasi matematis pada siswa SMA V Kota Jambi 9. (1) Proses penerapan mind mapping dengan pendekatan ilmiah untuk meningkatkan kemampuan komunikasi matematis siswa dapat berjalan dengan lancar sesuai rencana. Penerapan pemetaan pikiran telah memberikan pengalaman baru bagi siswa dan guru dan memberikan beberapa manfaat, manfaat pemetaan pikiran yang diperoleh antara lain: siswa menjadi semangat belajar, siswa mudah mengingat pelajaran dan siswa memperoleh pengalaman menggambar untuk menemukan hubungan antara satu konsep dan konsep lain dan guru lebih mudah menjelaskan materi pelajaran kepada siswa; (2) pada penilaian keterampilan komunikasi matematis siswa, dari data kuantitatif perolehan skor pada komunikasi matematis siswa memperoleh nilai yang cukup tinggi, yaitu pada siklus pertama nilai rata-rata yang diperoleh adalah 75,87 atau sekitar $77,2 \%$ pada siklus kedua. siklus ada peningkatan yaitu 80,1 atau sekitar $87,1 \%$.
\end{abstract}

Kata kunci:

Pemetaan Pikiran, pendekatan ilmiah, dan keterampilan komunikasi matematis

\begin{abstract}
Students' mathematical communication skills are still unsatisfactory, the average student error shows an error in expressing daily events in the language of mathematics. This is due to a lack of student understanding of the material that has been taught, and the level of students' creativity in recording important concepts contained in the content of the subject matter is still not satisfactory, student records tend to be still boring. The purpose of this study are to describe the implementation dan result of mind mapping in the scientific approach to improve students' mathematical communication skills. The type of research that the author is doing is included in classroom action research (CAR). The author uses interview, observation, test and documentation methods. As for the analysis, the author uses descriptive qualitative analysis techniques, namely in the form of qualitative data and quantitative data that the author obtained during direct observation in the field. The research findings show that the application of mind mapping in the scientific approach can improve mathematical communication skills in students of Jambi City Vocational High School 9. (1) The process of implementing mind mapping with a scientific approach to improve students' mathematical communication skills can run smoothly as planned. The application of mind mapping has provided new experiences for students and teachers and provides several benefits, the benefits of mind mapping obtained include: students become
\end{abstract}


the spirit of learning, students easily remember lessons and students gain drawing experience to find the relationship between one concept and another concept and the teacher easier to explain the subject matter to students; (2) on the assessment of students 'mathematical communication skills, from quantitative data the acquisition of scores on students' mathematical communication obtained a high enough value, namely in the first cycle the average value obtained was 75.87 or around $77.2 \%$, in the second cycle there was an increase namely 80.1 or around $87.1 \%$.

Keywords:

Mind Mapping, scientific approach, and mathematical communication skills

\section{PENDAHULUAN}

Pendidikan merupakan suatu kebutuhan yang sangat diperlukan oleh semua manusia di seluruh dunia. Pada dasarnya pendidikan di Indonesia merupakan pendidikan berkarakter yang unik sesuai dengan budaya Indonesia, dan sangat sejalan dengan tuntutan kecakapan abad 21. Salah satu usaha yang dilakukan pemerintah pada saat ini adalah dengan menggulirkan Kurikulum 2013 yang merupakan kurikulum nasional dengan terus menerus diperbaharui agar selaras dengan tuntutan pendidikan global dan tidak menyimpang dari nilai-nilai luhur bangsa Indonesia.

Kurikulum 2013 lebih ditekankan pada kompetensi dengan pemikiran kompetensi berbasis sikap, keterampilan dan pengetahuan.Dalam kurikulum 2013, pemerintah sudah menetapkan bahwa pendekatan yang harus digunakan dalam kurikulum 2013 adalah pendekatan saintifik. Pendekatan saintifik adalah proses pembelajaran yang dirancang sedemikian rupa agar siswa secara aktif mengkonstruksi konsep, hukum atau prinsip melalui tahapan-tahapan mengamati (mengidentifikasi atau menemukan masalah), merumuskan masalah, mengajukan atau merumuskan hipotesis, mengumpulkan data dengan berbagai teknik, menganalisis data, menarik kesimpulan dan mengomunikasikan konsep (Daryanto, 2014). Oleh karena itu, guru diharapakan memiliki inovasi-inovasi yang kreatif dan imajinatif dalam merancang suatu metode dan stategi pembelajaran.

Seorang guru professional akan mampu memilih metode, strategi, dan media pembelajaran dengan baik. Pemilihan media, metode, dan strategi pembelajaran disesuaikan dengan materi yang diajarkan, kondisi sekolah, dan kondisi siswa yang akan diajar, karena sebagus apapun pemilihan metodenya jika tidak disesuaikan dengan sarana dan prasarana yang ada disekolah maka hasilnya akan kurang maksimal, begitu juga sebaliknya apapun sarana dan prasarana yang dimiliki sekolah itu akan sia-sia jika guru tidak mampu memanfaatkannya dengan baik.

Pada saat melakukan observasi prapenelitian di SMP N 9 kota Jambi peneliti menemukan beberapa problematika dalam proses pembelajaran matematika, diantaranya adalah apresiasi siswa terhadap mata pelajaran matematika masih rendah, kurangnya interaksi antara guru dan siswa, siswa terlihat bosan, kemudiantuntutan menghapal rumus dan metode pembelajaran yang kurang tepat sehingga mengakibatkan pembelajaran kurang bermakna dan susana yang terlihat monoton.Fakta lain yang ditemukan adalah rendahnya kemampuan komunikasi matematis siswa. Kemampuan komunikasi matematis siswa masih melibatkan suatu konsep matematika saja siswa kesulitan dalam menghadapi 


\section{$\pi$ (Phi)}

permasalahan yang melibatkan beberapa konsep matematika. Fakta yang diberikan sehubungan rendahnya kemampuan komunikasi matematis yaitu dari hasil lembar jawaban siswa pada soal ulangan harian matematika, dari 31 siswa, jumlah yang menjawab benar hanya sebanyak $16,1 \%$, yang menjawab kurang tepat sebanyak $54,8 \%$, dan yang tidak menjawab sebanyak $29 \%$ dan rata-rata kesalahan siswa tersebut menunjukkan kesalahan dalam menyatakan peristiwa sehari hari dalam bahasa matematika.

Mencermati

berbagai

permasalahan dan realitas pembelajaran sebagaimana diuraikan tersebut, dalam pelaksanaan pembelajaran di kelas memerlukan suatu solusi dengan menggunakan pembelajaran yang disusun secara sistematis dan yang pada akhirnya dapat meningkatkan kemampuan komunikasi matematis yaitu dengan menerapkan Mind Mapping dalam pendekatan Saintifik.Menurut Buzan (2007) mind mapping dapat mempermudah siswa dalam mengingat, mendapatkan ide, memanfaatkan waktu dengan sebaikbaiknya sehingga menimbulkan pembelajaran yang menyenangkan untuk mendapatkan nilai yang lebih bagus.Mind mapping merupakan sebuah catatan siswa pada mata pelajaran matematika. Di dalam mind map terdapat simbol dan warna yang dapat merangsang ingatan siswa sehingga siswa dapat lebih mudah mengingat materi matematika. Hal ini bisa berupa peningkatan kemampuan mengingat informasi dan pemahaman materi pembelajaran melalui kegiatan mencatat yang menarik, efektif, dan efisien dengan menggunakan warna, simbol, gambar, tulisan, dan lain sebagainya.Penerapan mind mapping dalam pendekatan saintifik lebih menekankan pada kreatifitas berpikir siswa dengan membuat catatan yang menarik dan efektif sehingga siswa mudah untuk memahaminya.

Pendekatan saintifik dimaksudkan untuk memberikan pemahaman kepada siswa dalam mengenal, memahami berbagai materi menggunakan pendekatan ilmiah, bahwa informasi bisa berasal darimana saja, kapan saja, tidak bergantung pada informasi searah dari guru.Menurut Kosasih (2014) pendekatan saintifik merupakan pendekatan didalam kegiatan pembelajaran yang mengutamakan kreatifitas dan temuan-temuan siswa. Pendekatan Saintifik menuntut seorang guru agar mampu mengarahkan siswa untuk mengamati sesuatu dengan baik menggunakan panca inderanya untuk dapat mempereloh informasi, setelah memperoleh informasi siswa diharapkan mampu merumuskan masalah dari informasi yang diperoleh. Dalam pembelajaran Saintifik diorientasikan untuk membina siswa salah satunya adalah terampil dalam komunikasi matematis.

Menurut Schoen, Bean dan Zibarth (Hendriana dkk, 2017) bahwa komunikasi matematis adalah kemampuan menjelaskan algoritma dan cara unik menyelesaikan pemecahan masalah; mengonstruksi dan menjelaskan sajian fenomena dunia nyata secara grafik, kata-kata dan kalimat, persamaan, tabel, dan sajian secara fisik; memberikan dugaan tentang gambar-gambar geometri. Jadi, diharapkan siswa memiliki kemampuanmenyampaikan gagasan/ide matematis, baik secara lisan maupun tulisan serta kemampuan memahami dan menerima gagasan/ide matematis orang lain secara cermat, analitis, kritis, dan evaluatif untuk mempertajam pemahaman.Oleh karena itu kondisi pembelajaran yang diharapkan, diarahkan untuk mendorong siswa 


\section{$\pi$ (Phi)}

dalam mencari tahu dari berbagai sumber melalui observasi, dan bukan hanya diberi tahu.Adapun tujuan dari penelitian ini adalah untuk: mendeskripsikan pelaksanaan mind mapping dalam pendekatan saintifik untuk meningkatkan kemampuan komunikasi matematis siswa, dan (2) mendeskripsikan hasil penilaian kemampuan komunikasi matematis yang terjadi pada siswa setelah pembelajaran dilaksanakan dengan mind mapping dalam pendekatan saintifik.

\section{METODE PENELITIAN}

Penelitian ini menggunakan metode penelitian tindakan kelas (classroom action research). Penelitian tindakan kelas bertujuan untuk mengubah perilaku pengajaran guru, perilaku siswa dikelas, peningkatan atau perbaikan praktik pembelajaran.Menurut Carrdan Kemmis dalam Hermawan, Mujono dan Suherma (2010) "Penelitan Tindakan Kelas adalah salah satu bentuk refleksi diri yang dilakukan oleh para partisipan (guru, siswa atau kepala sekolah) dalam situasi-situasi social

(termasuk pendidikan) untuk memperbaiki rasionalitas dan kebenaran". Dalam penelitian PTK ini peneliti terlibat langsung di dalam kelas, peneliti sebagai pemberi arahan selama pembelajaran di dalam kelas berlangsung dan pengambil data tentang aktivitas siswa dan hasil kemampuan komunikasi matematis. PTK ini dilakukan secara kolaboratif partisipatoris, yaitu kerjasama antara peneliti (pengamat) dengan guru (pelaku tidakan). Dalam hal ini peneliti terlibat langsung dalam merencanakan tindakan, observasi, refleksi dan lainlain

Menurut Kemmis dan Mc.Taggart (Hermawan, Mujono dan Ayi, 2010) tahap penelitian tindakan kelas terdiri atas perencanaan, pelaksanaan tindakan, observasi dan refleksi dalam setiap tindakan, dengan berpatokan pada refleksi awal.Penelitian ini dilakukan secara bersiklus untuk mendapatkan hasil terbaik agar diperoleh data yang valid.Masing-masing siklus terdiri atas 4 tahapan, yakni tahap perencanaan, pelaksanaan tindakan, pengamatan (observasi), dan refleksi.

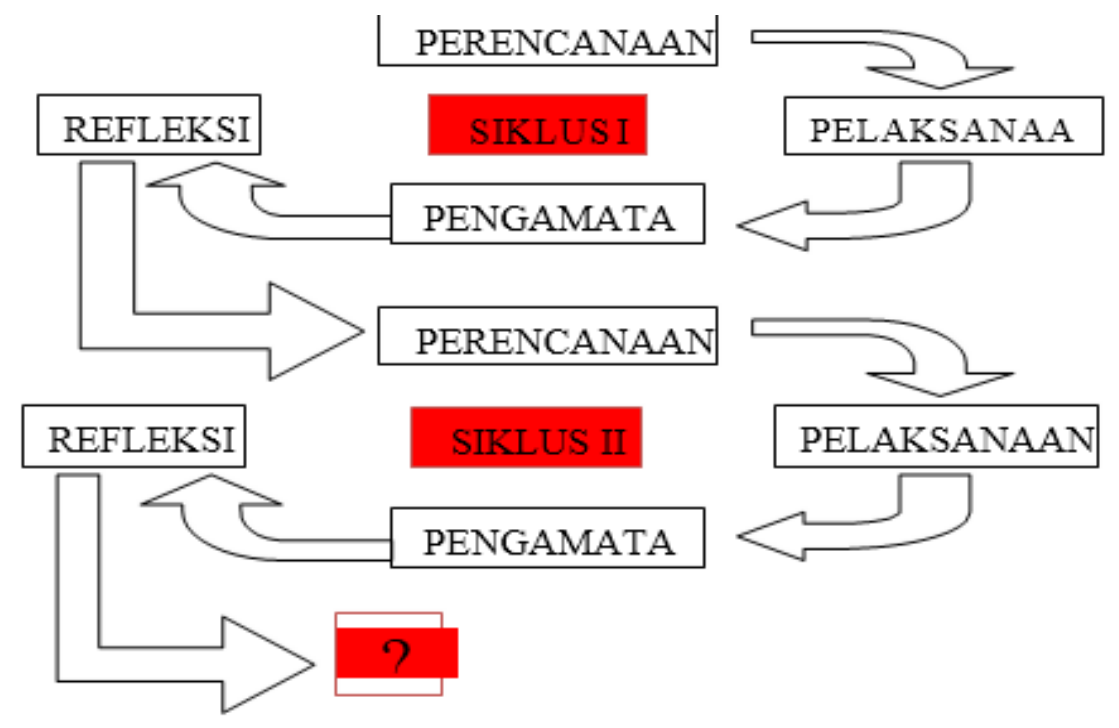

(Hermawan, Mujono dan Ayi, 2010)

Gambar 1.Model Desain PTK Kemmis dan McTaggart 


\section{$\pi$ (Phi)}

Peneliti melakukan kegiatan penelitian ini di kelas VII B SMP Negeri 9 yang belokasi di Jalan M.W Sulanjana Kec.Jambi Timur Kota Jambi.Penelitian ini dilaksanakan pada semester genap tahun ajaran 2017/2018.Subyek penelitian ini adalah siswa kelas VII B, karena hasil kemampuan komunikasi matematis pada kelas ini lebih rendah dibandingkan dengan kelas lainnya. Objek penelitian ini adalah kemampuan komunikasi matematis siswa kelas VII SMP Negeri 9 Kota Jambi tahun ajaran 2017/2018 melalui penerapan mind mapping dalam pendekatan saintifik.

Menurut Arikunto (2007), instrumen penelitian adalah suatu alat atau fasilitas yang digunakan oleh peneliti dalam mengumpulkan data agar lebih mudah dan hasilnya lebih baik dalam arti lebih cermat, lengkap, dan sistematis sehingga lebih mudah diolah. Untuk mengumpulkan data dalam penelitian ini, instrumen yang digunakan dalam penelitian ini adalah: (1) Lembar observasi/pengamatan. Lembar observasi yang digunakan dalam penelitian ini adalah lembar observasi untuk memperoleh gambaran tentang aktivitas selama prosespembelajaran dengan menerapkan mind mapping dalam pendekatan saintifik. (2) Tes. Tes yang diberikan setiap akhir siklus digunakan sebagai umpan balik untuk mengetahui perubahan kemampuan komunikasi matematis siswa yang terjadi akibat dari penerapan mind mapping dalam pendekatan saintifik.

Analisis Data yang diperoleh dari setiap tindakan yang dilakukan dianalisis untuk memastikan bahwa dengan menerapkan mind map dalam pendekatan saintifik dapat meningkatkan kemampuan komunikasi matematis siswa. Data yang bersifat kualitatif yang terdiri dari hasil observasi dan dokumentasi dianalisis secara kualitatif.Jika yang dikumpulkan berupa data kuantitatif, makaanalisis dilakukan secara kuantitatif pula. Proses tersebut dilakukan melaluitahap: menyederhanakan, mengklasifikasi, memfokuskan,

mengorganisasi(mengaitkan gejala) secara sistematis dan logis, serta membuat abstraksi ataskesimpulan makna hasil analis (Soedarsono, 2001). Menurut Milles dan Hubberman (2001), teknik analisis data terdiri dari tigatahap pokok, yaitu reduksi data, paparan data dan penarikan kesimpulan.Reduksi data merupakan proses pemilihan data yang relevan, penting,bermakna, dan data yang tidak berguna untuk menjelaskan tentang apa yangmenjadi sasaran analisis. Langkah yang dilakukan adalah menyederhanakandengan membuat jalan fokus, klasifikasi dan abstraksi data kasar menjadi datayang bermakna untuk dianalisis. Data yang telah direduksi selanjutnya disajikan dengan caramendeskripsikan dalam bentuk paparan data yang memungkinkan untukditarik kesimpulan. Akhir dari kegiatan analisis adalah penarikan kesimpulan.

Untuk mengetahui perubahan hasil tindakan, jenis data yang bersifat kuntitatif yang didapatkan dari hasil evaluasi dianalisis menggunakan rumus:

$$
\begin{aligned}
& \mathrm{P}=\frac{\text { Post rate }- \text { Bese rate }}{\text { Base rate }} \mathrm{x} \\
& 100 \%
\end{aligned}
$$

Keterangan:

$\mathrm{P}=$ Presentase Peningkatan

Post rate $=$ Nilai rata-rata sesudah tindakan

Base rate = Nilai rata-rata sebelum tindakan (Hamzah, 2007)

\section{HASIL DAN PEMBAHASAN}

Sebelum tindakan dilaksanakan, terlebih dahulu peneliti mengadakan pre test.Pre test dilaksanakan untuk 


\section{$\pi$ (Phi)}

mengetahui pengetahuan awal siswa dan kesiapan dalam belajar serta kreativitas siswa dalam mencatat. Pada pelaksanaan pre test, siswa terlihat kurang antusias karena kurang adanya persiapan dalam mempelajari materi yang ada pada pertemuan ini.Rata-rata pemahaman siswa terhadap konsep matematika masih kurang.Kreativitas siswa dalam mencatat kata-kata penting terkait dengan materi segi empat dan segitiga juga masih kurang, siswa terlihat masih malas untuk mencatat.Hasil kreativitas mencatat dan kemampuan komunikasi matematis siswa kurang maksimal. Dari hasil evaluasi pada saat pre test, didapatkan rata-rata kelas pada tes kemampuan komunikasi matematis sebesar 42,81.

Pembahasan dalam PTK ini didasarkan pada hasil pengamatan yang dilanjutkan dengan kegiatan evaluasi dan refleksi. Berdasarkan hasil penelitian siklus I dan II menunjukkan bahwa pembelajaran matematika dengan menerapkan mind mapping dalam pendekatan saintifikmengalami peningkatan, baik dari segi peningkatan keaktifan siswa, dan kemampuan komunikasi matematis siswa selama proses pembelajaran berlangsung.Penelitian ini dilaksanakan selama 2 siklus dan masing-masing siklus dilaksanakan selama 2 kali pertemuan. Jadi penelitian ini dilaksanakan sebanyak 4 kali pertemuan.

Berdasarkan hasil pengamatan dan refleksi pada siklus I pada pertemuan pertama ini jumlah siswa yang masuk sebanyak 31 siswa (100\%). Aktivitas siswa pada pertemuan pertama ini masih relatif rendah atau belum sesuai yang diharapkan. Siswa belum semuanya aktif dalam mengikuti pembelajaran. Masalah yang dihadapi yaitu siswa masih banyak yang mengobrol dengan teman-temannya pada saat diskusi berlangsung. Aktifitas belajar yang kurang maksimal disebabkan karena siswa belum terbiasa dengan penerapan mind mapping yang baru pertama kali diterapkan pada pembelajaran matematika dikelas VII B. Pada pertemuan kedua ini jumlah siswa yang masuk sebanyak 30 siswa dan 1 orang siswa tidak hadir. Aktivitas siswa pada pertemuan kedua ini siswa sudah bisa mengikuti pelajaran dengan baik, siswa sudah mulai aktif dalam kerja kelompok dan siswa sudah mulai bisa bekerjasama dengan temannya yang lain meskipun masih ada yang mengobrol dengan temannya yang lain. Dari latar belakang tersebut kemudian peneliti melanjutkan pembelajaran ke siklus II.

Dari hasil aktivitas siswa pada siklus ke II mengalami peningkatan. Berdasarkan pengamatan pada siklus II siswa lebih aktif mengikuti proses pembelajaran dikelas, tidak malu lagi bertanya maupun menjawab pertanyaan dari guru atau siswa lain. Siswa telah mampu berdiskusi secara tertib dan baik. Siswa juga banyak berani menyampaikan maupun menanggapi hasil diskusi. Masing-masing pasangan ingin terlihat lebih menonjol dan mendapatkan nilai lebih baik. Pembelajaran yang dikombinasikan dengan mind mapping menciptakan suasana yang menyenangkan, siswa terlibat langsung dalam pembelajaran. Penerapan mind mappingtelah memberikan pengalaman baru bagi siswa maupun guru dan memberikan beberapa manfaat, manfaat mind mapping yang diperoleh antara lain: siswa menjadi semangat belajar, siswa mudahmengingat pelajaran dan siswa memperoleh pengalaman menggambar untuk menemukan hubungan konsep yang satu dengan konsep yang lain dan gurulebih mudah menjelaskan materi pelajaran pada siswa. Adapun rata-rata aktivitas siswa pada setiap siklus dalam 
proses pembelajaran terlihat pada tabel dibawah ini:

Tabel 1. Rata-rata Aktivitas Siswa Pada Siklus I, dan II

\begin{tabular}{lcc}
\hline \multicolumn{1}{c}{ Aspek yang diamati } & Siklus I (\%) & Siklus II (\%) \\
\hline 1. Mengajukan pertanyaan & 9,79 & 24,19 \\
2. Menanggapi respon siswa lain & 13,1 & 17,74 \\
3. Menjawab pertanyaan guru & 65,81 & 75,5 \\
4. Memperhatikan penjelasan guru & 80,38 & 87,1 \\
5. Diskusi kelompok & 85,27 & 95,16 \\
6. Diskusi kelas & 85,27 & 98,77 \\
\hline
\end{tabular}

Secara keseluruhan proses pembelajaran pada siklus I dan II berlangsung baik. Hal tersebut didukung oleh peningkatan aktivitas siswa dan kinerja guru sehingga berdampak pada meningkatnya kemampuan komunikasi matematis siswa. Untuk melihat peningkatan kemampuan komunikasi matematis, pada akhir pertemuan setiap siklus dilakukan tes untuk mengetahui sejauh mana mind mapping dapat mempengaruhi kemampuan komunikasi matematis siswa. Dari hasil penilaian pada siklus I dapat dikatakan bahwa tingkat keberhasilan kelas dari 31 siswa, yang dinyatakan lulus sebanyak 26

Tabel 2. Rata-rata Post-tes Kemampuan Komunikasi

\begin{tabular}{c} 
Pre-test \\
\hline 42,81 \\
tabel di atas dapat diketahui
\end{tabular}

Dari tabel di atas dapat diketahui bahwa bahwa penerapan mind mapping dalam pendekatan saintifik ini terbukti dapat meningkatkan kemampuan komunikasi matematis. Terlihat dari adanya peningkatan skor dari pre test yang semula nilai rata-rata kelas dari pre test sebesar 42,81 meningkat menjadi 75,87 atau sekitar 77,2\% pada siklus I dan nilai rata-rata kelas dari pre test sebesar 42,81 meningkat menjadi 80,1 atau sekitar $87,1 \%$ pada siklus ke II. Bukti-bukti ini sesungguhnya mendukung apa yang diungkapkan oleh teori TonyBuzan (2007:56) yang mengatakan bahwa mind map merupakan suatu model yang berguna untuk memaksimalkan kreativitas manusia, sangat memudahkan manusia mengingat informasisedangkan menurut

$75,87 \quad 80,1$

siswa. Sedangkan yang gagal sebanyak 5 siswa karena skor tesnya kurang dari 75, sesuai dengan KKM (kreteria ketuntasan minimum) yang telah ditentukan oleh guru matematika di kelas VIIB. Kemudian Pada Siklus II terjadi peningkatan, dapat dikatakan bahwa tingkat keberhasilan kelas dari 31 siswa, yang dinyatakan lulus sebanyak 31 siswa. Sedangkan yang gagal tidak ada, karena nilai yang diperolehlebih dari KKM (kreteria ketuntasan minimum) sebesar 75 . Adapun nilai rata-rata tes kemampuan komunikasi matematis setiap siklus terlihat pada tabel dibawah ini: -tes Kemampuan Komunikasi
est Siklus I $\quad$ Post-test Siklus II

teori Ingemar Svantesson (2004) yang mengatakan bahwa mind map akan membantu siswa untuk mengembangkan kreativitas juga kemampuan analisis dan logika.

$$
\text { Peningkatan kemampuan }
$$

komunikasi matematis siswa menggunakan mind mapping dalam pendekatan saintifikjuga diikuti tanggapan yang positif dari siswa terhadap proses pembelajaran tersebut. Dalam kegiatan pembelajaran siswa tampak senang dan antusias mengikuti diskusi.Hasil penelitian dan pembahasan di atas dapat disimpulkan bahwa penerapan mind mapping dalam pendekatan saintifik dapat meningkatkan kemampuan komunikasi matematis siswa pada kelas VIIB. 


\section{$\pi$ (Phi)}

Peningkatan tersebut dari $77,2 \%$ menjadi $87,1 \%$.

\section{KESIMPULAN}

Berdasarkan penelitian yang telah dilakukan, dapat diambil kesimpulan sebagai berikut:

1. Proses pelaksanaan mind mapping dengan pendekatan saintifikuntuk meningkatkan kemampuan komunikasi matematis siswa dapat berjalan dengan lancar sebagaimana yang telah direncanakan. Penerapan mind mappingtelah memberikan pengalaman baru bagi siswa maupun guru dan memberikan beberapa manfaat, manfaat mind mapping yang diperoleh antara lain: siswa menjadi semangat belajar, siswa mudahmengingat pelajaran dan siswa memperoleh pengalaman menggambar untuk menemukan hubungan konsep yang satu dengan konsep yang laindan gurulebih mudah menjelaskan materi pelajaran pada siswa.

2. Pada penilaian kemampuan komunikasi matematis siswa, dari data secara kuantitatif perolehan skor komunikasi matematis siswa memperoleh nilai yang cukup tinggi yaitu pada siklus I nilai rata-rata yang diperoleh sebesar 75,87 atau sekitar 77,2\% , pada siklus II mengalami peningkatan yaitu 80,1 atau sekitar $87,1 \%$.

\section{DAFTAR PUSTAKA}

Arikunto, Suharsimi, dkk. 2007. Penelitian Tindakan kelas. Jakarta: Bumi Aksara

Buzan, Tony. 2007. Buku Pintar Mind mapping Untuk Anak.Jakarta: Gramedia
Daryanto. 2014. Pendekatan Pembelajaran Saintifik Kurikulum 2013. Yogyakarta: Gava Media

Hendriana, Eti Rohaeti, dan Utari Sumarmo. 2017. Hard Skills dan Soft Skills Matematik Siswa. Bandung: Refika Aditama.

Hermawan, R. Mujono. dan Suherman, A. (2010). Metode Penelitian Pendidikan SD. Edisi kedua. Bandung: UPI PRESS

Kosasih.2014. Strategi Belajar dan Pembelajaran Implementasi Kurikulum 2013. Bandung: Yrama Widya.

Matthew, B Miles dan A, Michael Huberman.2001. Analisis Data Kualitatif. Jakarta: Universitas Indonesia

Svantesson, Ingemar. 2004. Learning Maps and Memori Skills. Jakarta:Gramedia

Soedarsono, FX. 2001. Aplikasi Penelitian Tindakan Kelas. Jakarta: Departemen Pendidikan Nasional

Uno, B. Hamzah. 2007. Model Pembelajaran. Jakarta: PT. Bumi Aksara 